Report No. BMI-1180

Metallurgy and Ceramics

(TID-4500, 13th Ed.)

Contract No. W-7405-eng-92

INERT-GAS-SHIELDED CONSUMABLE-ELECTRODE

WELDING OF MOLYBDENUM

by

Norman E. Weare

Robert E. Monroe

David C. Martin

April 25, 1957

BATTELLE MEMORIAL INSTITUTE

$505 \mathrm{King}$ Avenue

Columbus 1, Ohio 


\section{DISCLAIMER}

This report was prepared as an account of work sponsored by an agency of the United States Government. Neither the United States Government nor any agency Thereof, nor any of their employees, makes any warranty, express or implied, or assumes any legal liability or responsibility for the accuracy, completeness, or usefulness of any information, apparatus, product, or process disclosed, or represents that its use would not infringe privately owned rights. Reference herein to any specific commercial product, process, or service by trade name, trademark, manufacturer, or otherwise does not necessarily constitute or imply its endorsement, recommendation, or favoring by the United States Government or any agency thereof. The views and opinions of authors expressed herein do not necessarily state or reflect those of the United States Government or any agency thereof. 


\section{DISCLAIMER}

Portions of this document may be illegible in electronic image products. Images are produced from the best available original document. 
ABSTRACT . . . . . . . . . . . . . . . . . . . 1

INTRODUCTION . • . . . . . . . . . . . . . . . . . . . . . . . . 1

MATERIALS . . . . . . . . . . . . . . . . . . . . 2

EXPERIMENTAL PROCEDURES. . . . . . . . . . . . . . . . . . 5

Equipment . . . . . . . . . . . . . . . . . . . 5

Cleaning Methods. . . . . . . . . . . . . . . . 47

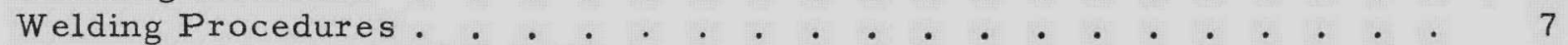

Evaluation of Welding Conditions. . . . . . . . . . . . 8

EXPERIMENTAL RESULTS . . . . . . . . . . . . . . . . . . . 9

Arc Stability and Metal Transfer. . . . . . . . . . . . . 9

Current Density . . . . . . . . . . . . . . . 10

Direct-Current Polarity . . . . . . . . . . . . . 10

Shielding Gas . . . . . . . . . . . . . . . . . 12

Shielding. . . . . . . . . . . . . . . . 12

Emissive Coatings . . . . . . . . . . . . . 12

Spatter . . . . . . . . . . . . . . . . . 14

Weld-Bead Contour and Penetration. . . . . . . . . . . . 14

Cracking. . . . . . . . . . . . . . . . . . . . 15

Porosity. . . . . . . . . . . . . . . . . . 16

Butt Joints . . . . . . . . . . . . . . . . . 16

Comparison of Weldments . . . . . . . . . . . . . . 17

FUTURE STUDIES . . . . . . . . . . . . . . . . . . . . . . 22

REFERENCES . . . . . . . . . . . . . . . . . . . . . . 23 


\title{
INERT-GAS-SHIELDED CONSUMABLE-ELECTRODE WELDING OF MOLYBDENUM
}

\author{
Norman E. Weare, Robert E. Monroe, \\ and David C. Martin
}

\begin{abstract}
As part of the over-all program to improve the ductility of molybdenum weldments, studies were initiated to adapt the inert-gas-shielded consumable-electrode arc-welding process to molybdenum. This report covers the work required to improve metal transfer and arc stability in molybdenum arcs before starting complete evaluation of this welding process.
\end{abstract}

Arc stability and metal transfer could be improved to the greatest extent by using direct current, straight polarity, an electrode wire coated with a compound to increase the emission of electrons, and a helium shield. _These same conditions also produced the best weld-bead contour, and lessened the amount of weld-metal cracking due to shrinkage stresses developed in the weldment. Porosity was not evident when using either a leading-trailing shield or a dragging shield, and when welding on arc-cast molybdenum.

Metallographic and bend-test comparisons were made between these welds and tungsten-arc welds in 1/8-in.-thick molybdenum. The weld-metal grain size was about the same for both weldments. Room-temperature bend-test ductility was very low for both weldments. The results of this comparison indicated that the inert-gas-shielded consumable-electrode welding process may have its best application in welding thick molybdenum plate, whereas tungsten-arc welding would be better for welding sheet $1 / 8$ in. thick or less.

\section{INTRODUCTION}

Methods of improving the low-temperature ductility of molybdenum weldments have been under investigation for several years. One phase of this investigation was devoted to adapting the inert-gas-shielded consumable-electrode welding process to molybdenum. Studies of arc stability and metal transfer in molybdenum arcs, which were immediate problems in adapting the consumable-electrode process for molybdenum welding, are discussed in this report. The results of some preliminary tests of the properties of joints made with the consumable-electrode process are reported.

One of the major deterrents to the use of molybdenum in high-temperature reactors is the low room-temperature ductility of molybdenum weldments. In recent years, important advances have been made in improving weldment room-temperature ductility. One investigation( 1 ) made to compare tungsten-arc welds in a large number of alloys indicated that (1) weldments in carbon-deoxidized molybdenum were as ductile as weldments in experimental high-purity titanium-neutralized molybdenum, and (2) weldment room-temperature bend ductility was improved by grinding the weld surface. Another study $(2)$ was made to ascertain the effects of variables on the ductility of tungsten-arc welds in molybdenum and to determine if welds of consistent ductility could be made in different heats of arc cast molybdenum of about the same carbon content.

(1) References at end of report. 
The bend-test results for welds made in the latter study indicate that there is a limit to tungsten-arc weldment ductility, owing to the large weld-metal grain size. The maximum average permanent bend angle at room temperature for welds made in a highpurity dry-box atmosphere was about $65 \mathrm{deg}$, as determined by a fast bend test. Tungsten-arc welds made outside the dry box, using inert-gas shielding, were not as ductile as those in the dry box. It was thought that the inert-gas-shielded consumableelectrode process would produce weldments with a finer weld-metal grain size and a narrower heat-affected zone, due to a more rapid energy input. A smaller weld-metal grain size would increase ductility and would increase the tolerances for impurities if the molybdenum were welded outside a dry box. All weldments made during the course of this investigation were made in air with an inert-gas shield, using direct current.

The use of a consumable electrode introduced variables which were not present with the tungsten-arc welding process. The fact that the electrode was being consumed and metal was being transferred through the arc gave rise to problems of metal transfer and arc stability. The results of studies reported here indicate that arc stability and metal transfer can be improved by (1) using high current densities, (2) using helium rather than argon for shielding, and (3) coating the arc cathode with a compound to improve the emission of electrons. Other studies were made of direct-current polarity and shielding devices.

When good arc conditions were established, slight variations in parameter, principally in weld speed, were made to obtain an acceptable weld-bead contour. It was found that the best weld-bead contour could be obtained by welding in helium, with direct current, straight polarity (electrode negative), and with an emissive coating on the electrode.

Weld cracking and porosity were minor problems which were virtually eliminated once good welding conditions were established. Preliminary tests with butt joints indicated further studies of joint design are necessary. An inconclusive comparison was made between a tungsten-arc weld and a consumable-electrode weld in 1/8-in, -thick molybdenum sheet. There appeared to be very little difference in weldment macrostructure or ductility for weldments in $1 / 8$-in, -thick sheet.

\section{MATERIALS}

Arc-cast carbon-deoxidized molybdenum sheet ( $1 / 32$ through $1 / 2$ in. thick) and electrode wire $(0.020,0.040$, and $0.062 \mathrm{in}$, in diameter) were used for this study. Metallographic examinations of the sheet were made. The photomicrographs in Figure 1 show that none of the sheet was in what could be considered the fibered condition. The 3/8- and 1/2-in.-thick plate had more elongated grains near the surface. The chilling effect of the rolls cooled the plate surface enough to allow more cold work to be put into the surface layer. Vickers hardness readings were taken for all the sheet and indicated that very little cold reduction occurred in the interior of the $3 / 8-$ and $1 / 2$ in. -thick plate. The available data for the molybdenum sheet are given in Table 1 . Fabrication data were not available for the sheet or wire.

Previous experience with 1/16-in, -thick molybdenum sheet with a coarse elongated grain structure has shown this type of grain structure to be much less ductile at room temperature than a fibered grain structure. (2) Room-temperature bend tests 
a. Sheet C27 (1/32 In. Thick)

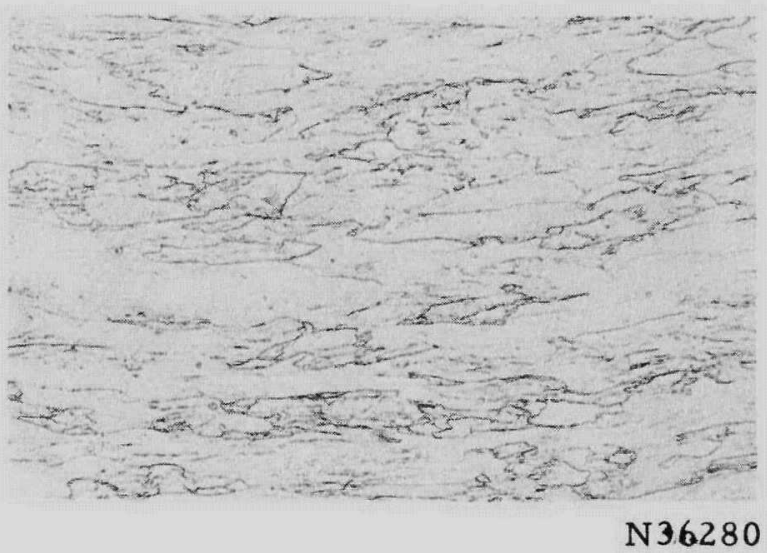

c. Sheet C29 (1/8 In. Thick)

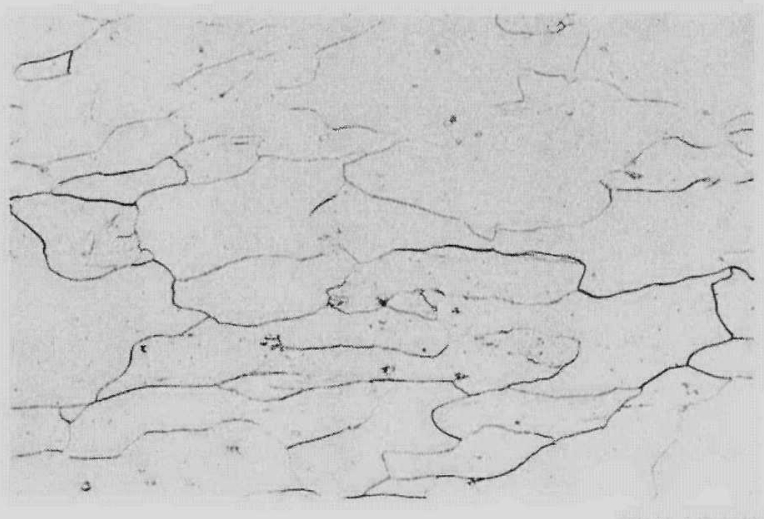

N36282 b. Sheet C28 (1/16 In. Thick)

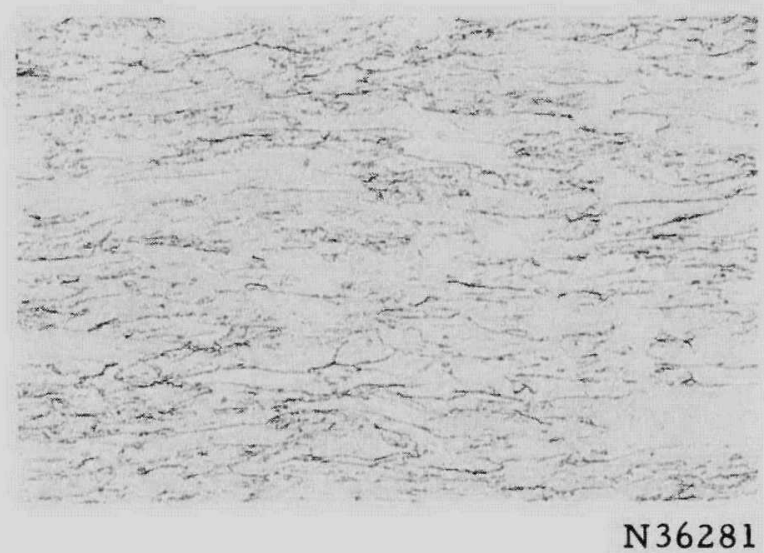

d. Sheet C 30 (1/4 In. Thick)

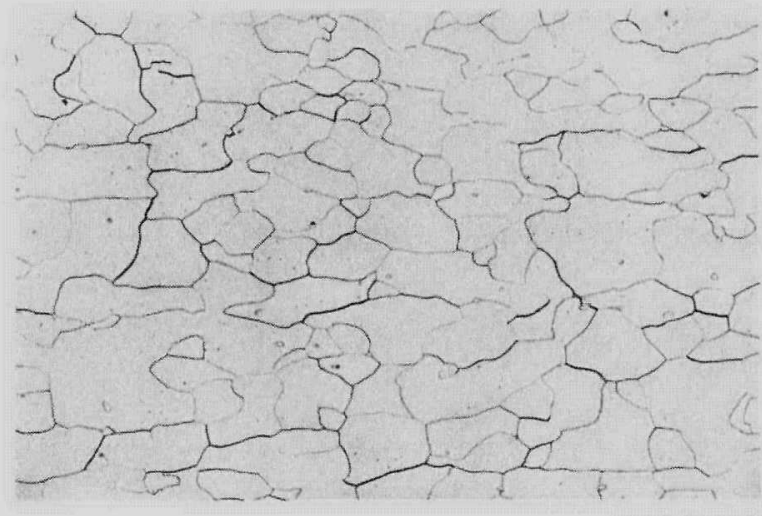

N36283

e. Sheet C31 (3/8 In. Thick)

f. Sheet C 32 (1/2 In. Thick)

FIGURE 1. TYPICAL INTERIOR MICROSTRUCTURE OF MOLYBDENUM SHEET FOR WELDING STUDY

Longitudinal sections. Murakami's etch; 100X. 
TABLE 1. SUMMARY OF AVAILABLE DATA ON MOLYBDENUM SHEET FOR WELDING STUDIES

\begin{tabular}{|c|c|c|c|c|c|}
\hline Sheet & $\begin{array}{c}\text { Thickness, } \\
\text { in. }\end{array}$ & $\begin{array}{c}\text { Carbon } \\
\text { Content, } \\
\text { w/o }\end{array}$ & Microstructure & $\begin{array}{c}\text { DPH } \\
\text { (10-Kg Load) } \\
\end{array}$ & $\begin{array}{c}\text { Average Bend } \\
\text { Angle at } \\
25 \mathrm{C}(\mathrm{a}) \text {, deg }\end{array}$ \\
\hline $\mathrm{C} 27$ & $1 / 32$ & 0.019 & Elongated fine grains & 274 & -- \\
\hline $\mathrm{C} 28$ & $1 / 16$ & 0.019 & Elongated coarse grains & 284 & -- \\
\hline $\mathrm{C} 29$ & $1 / 8$ & 0.011 & Elongated coarse grains & 257 & 24 \\
\hline C 30 & $1 / 4$ & 0.019 & Elongated coarse grains & 251 & -- \\
\hline C 31 & $3 / 8$ & 0.019 & $\begin{array}{l}\text { Elongated very coarse } \\
\text { grains }(\mathrm{b})\end{array}$ & 210 & -- \\
\hline $\mathrm{C} 32$ & $1 / 2$ & 0.019 & $\begin{array}{l}\text { Nearly equiaxed coarse } \\
\text { grains (b) }\end{array}$ & 189 & - \\
\hline
\end{tabular}

(a) After stress relief at $1800 \mathrm{~F}$ for $1 \mathrm{hr}$ in flowing helium.

(b) The grains were more elongated near the sheet surface. 
were made on Sheet $\mathrm{C} 29$ only, and the bend ductility after stress relief $(1800 \mathrm{~F}, 1 \mathrm{hr}$, in helium) was found to be poor. The average permanent bend angle after fracture was $24 \mathrm{deg}$. This does not compare favorably with the 75-deg average bend angle for $1 / 8$-in. -thick sheet (C 3 ) used in a previous study. (1)

Three electrode wire sizes were available for this study: $0.020,0.040$, and $0.062 \mathrm{in}$. in diameter. Most of the work was conducted with the 0.040-in.-diameter wire. The carbon content of all wire was $0.022 \mathrm{w} / \mathrm{o}$.

\section{EXPERIMENTAL PROCEDURES}

The consumable-electrode welding process involves more variables than the tungsten-arc process previously used for molybdenum. In the process, the tip of the electrode is melted and metal is transferred through the arc as a spray of fine particles. Additional variables introduced by the use of a consumable electrode are: (1) arc stability, (2) metal transfer, and (3) electrode-burnoff rate. These variables are all interrelated to some extent. This section describes the equipment, cleaning method, welding procedures and methods used to evaluate welds.

\section{Equipment}

The equipment used for this study consisted of a 900 -amp d-c welding generator which maintained a constant arc voltage, a welding head which provided a constant electrode-feed rate, and a moving carriage. The current was regulated by the welding generator to that required to maintain a given electrode burnoff rate. A constantelectrode-feed-rate welding head was used for this study, since it provided good control of welding variables. Current and arc voltage were measured by recording meters.

Three types of gas shields were used in this study. These were (1) a standard shielding cup, (2) a leading-trailing shield, and (3) a dragging shield. The standard shielding cup (Figure 2a) was a water-cooled cup with a 1-in.-diameter gas orifice. Protection was provided for the molten weld pool and the filler wire. To improve the shielding, a water-cooled leading-trailing shield unit was built (Figure $2 \mathrm{~b}$ ). The leading portion of the shield protected the unwelded molybdenum ahead of the arc while the trailing portion protected the completed weld. This unit was made to fit the shielding cup. A gas baffle consisting of several layers of fine-mesh copper screen was brazed into the bottom of the shield. This gas baffle distributed the gas flow evenly. Gas was admitted from the leading and trailing ends of the shield.

To further improve the shielding, a dragging shield (Figure 2c) was constructed which could slide in direct contact with the molybdenum being welded. When this shield was purged with helium, it acted as a small inert-gas welding chamber. This shield functioned much the same as the dragging shield described in BMI-1139(2), which was used for making tungsten-arc welds for comparison with consumable-electrode welds.

To conserve material, a jig was made to hold 1 by $4-i n$. specimens of $1 / 8$ through 1/2-in, -thick plate. A copper backup bar was recessed so that a 1/16-in. molybdenum 


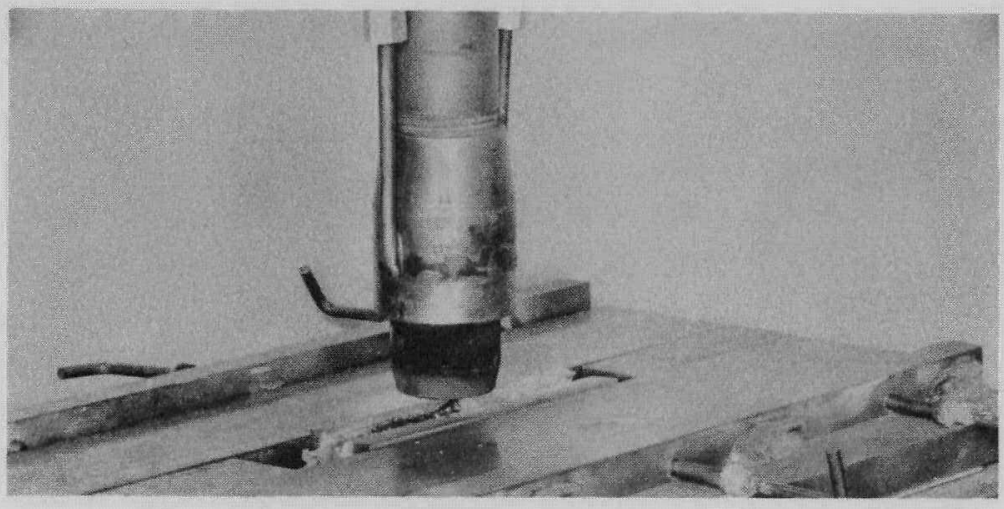

N38030

a. Standard 1-In. -ID Shielding Cup

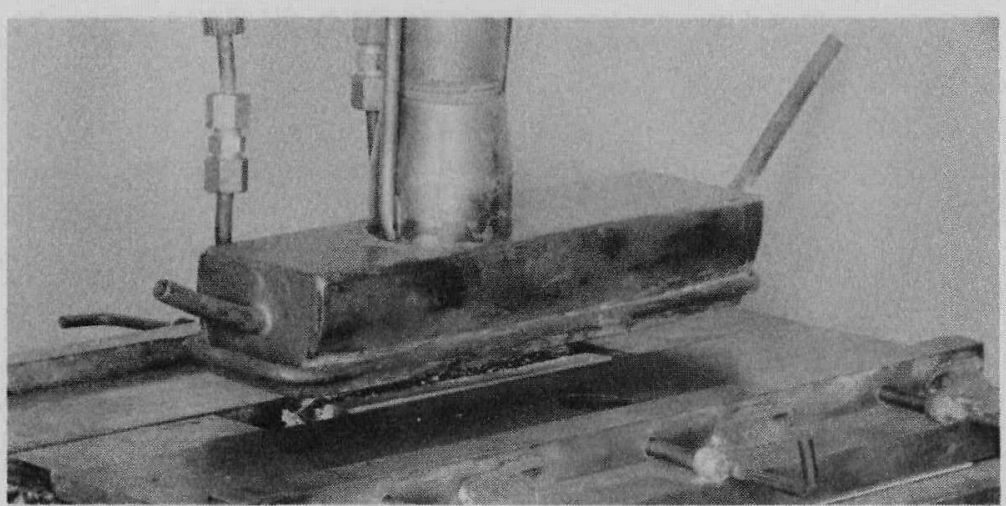

N38029

b. Leading-Trailing Shield Unit

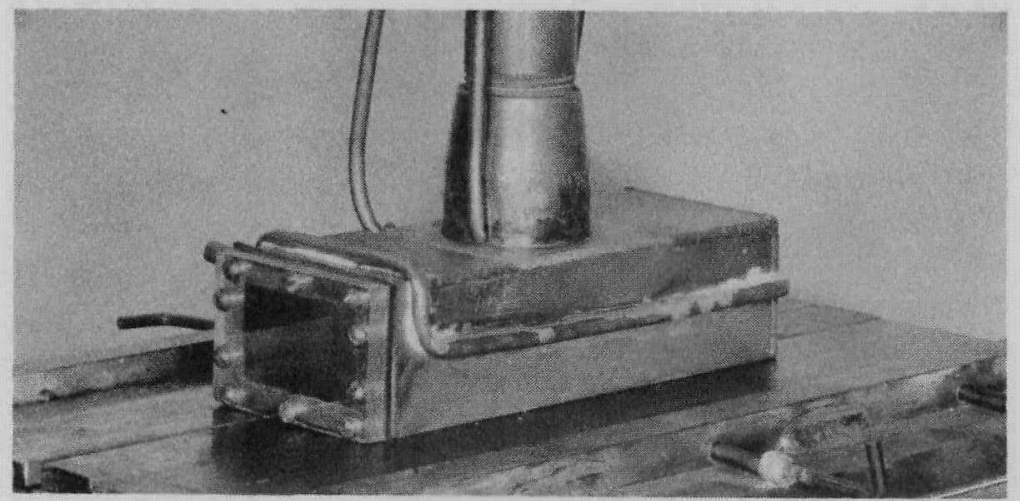

N38028

c. Dragging Shield

FIGURE 2. SHIELDING DEVICES FOR THE INERT-GAS-SHIELDED CONSUMABLE-ELECTRODE WELDING OF MOLYBDENUM 
backing strip could be used to prevent copper pickup when penetration was complete. The weld specimens were held in a "picture frame" by copper plates on either side, of the same thickness as the molybdenum being welded. Molybdenum starting and runoff tabs backed by copper bars completed the picture frame. This jig provided a flat surface on which the dragging shield could slide. This jig is shown partially in Figure 2.

\section{Cleaning Methods}

Welding conditions were evaluated by making a series of bead-on-plate welds on single plates of molybdenum. In this study, only test joints were cleaned in the chromic acid etch normally used for cleaning molybdenum before welding. To save time and trouble, the molybdenum sheet was cleaned between welds simply by abrading it with emery paper. Previous investigations had shown that we!ds made on sheet which had been abraded had nearly as good ductility as welds on sheet rleaned in chromic acid.

The wire had a black oxide coating on its surface when it was received from the fabricator. This heavy oxide was removed by etching in the chromic acid solution. The wire was then wound on a spool and placed on the welding head. Slight oxide films formed on the wire were then removed by running out a length of wire and polishing it with emery paper. The wire was then rewound on the spool and used for welding.

\section{Welding Procedures}

To insure adequate shielding with the leading-trailing and dragging shields, the shields were purged with inert gas for about $30 \mathrm{sec}$ prior to welding. When the weldstart switch was closed, a time delay allowed about $5 \mathrm{sec}$ for the purging of the shielding cup. At the end of this time delay, controls simultaneously initiated the electrodewire feed and the specimen carriage, and completed the power circuit for the arc. The wire contacted the molybdenum plate and struck the arc. During the welding operations, the electrode feed (burnoff rate) was constant, and the welding generator maintained a constant preset arc voltage. The current output of the generator was the amount required to maintain a constant arc voltage, regardless of the burnoff rate. In order to determine the effect of single variables, all the other welding conditions were held nearly constant. However, when changing $d-c$ polarity or type of shielding gas, it was necessary to change other conditions to compensate for the differences in arc and metal-transfer characteristics.

As will be discussed in a later section, the arc was very unstable when welding on oxide-free sheet (reverse polarity) or when welding with oxide-free wire (straight polarity). The arc stability could be improved by coating the cathode (negative electrode) with a compound which increased the emission of electrons. For reverse polarity, the plate being welded was first cleaned and then a dilute solution of cesium chloride in distilled water was painted on the joint and allowed to dry, leaving a thin film of the chloride. When straight polarity was used, the clean electrode wire was coated with the chloride.

If the arc appeared steady, adjustments were then made in the weld speed to produce a good weld-bead contour with no irregularities. When welding conditions were 
established which appeared to be good, single vee-joints, square butt joints, or beadon-plate welds were made to further evaluate these conditions.

Several butt joints were prepared and welded using conditions chosen from the bead-on-plate welds. Single vee-joints with 15-, 20-, 30-, and 45-deg bevels were prepared from 1/4-in. plate, and 20 -deg bevels were used on $3 / 8$ - and $1 / 2$-in. -thick plate. Square butt joints were also made in $1 / 4-$ in. plate. All joints were made using 0.040-in,-diameter electrode wire. Some bead-on-plate welds were made using $0.062-$ in.-diameter electrode wire. No welds were made with 0.020-in,-diameter electrode wire, since the welding equipment required modification to facilitate its use with this small-diameter wire.

Butt joints were prepared from two pieces of plate $1 / 2$ in. wide by 4 in. long. The bevel was ground and the halves were tacked together by tungsten-arc welding in a dry box. The joints were then placed in the picture-frame jig described in a previous section. A 1/16-in.-thick molybdenum backup strip was used for all joints to prevent pickup of copper during welding.

\section{Evaluation of Welding Conditions}

During the course of this investigation, numerous bead-on-plate welds required rapid evaluation to determine good welding conditions for the inert-gas-shielded consumable-electrode welding of molybdenum. Welding conditions were evaluated by visual examination of the arc and the completed weld.

The arc was observed to determine arc stability. An unstable arc would sputter, wander, or vary in length. When the arc was unstable, the voltage and current traces were very irregular. Conversely, a stable arc was steady and had smooth arc-voltage and current traces.

The weld bead was examined for weld-bead contour and, occasionally, for penetration. If a weld bead had a good contour and sufficient penetration, and the arc was stable, the welding conditions were considered good. Poor weld-bead contours indicated that a change in some variable was necessary.

Radiographic examinations were not made on weldments to determine the extent of porosity and cracking. Porosity was sometimes visible on the surface of the welds. Metallographic examinations were used to supplement other observations on the best welds produced.

Bend tests were made at room temperature on 1/8-in. -thick sheet and weldments. The specimens were ground flat and the tension face was rough polished, since it had previously been shown that this improved weldment ductility. The sheet and weldments were bent to fracture, and the permanent bend angle after fracture was measured. The testing conditions are listed below: 
Type of test

Testing temperature

Deflection rate

Strain rate

Specimen dimension
Simple single-point-loaded bend test

$25 \mathrm{C}$

1 ipm

0.032 in. per in. per sec at start of bend

$1 / 8$ by $1 / 4$ by approximately 1 in.

This test is described in detail in BMI-1037. (1)

\section{EXPERIMENTAL RESULTS}

Initial welding tests defined the problems which required solution before the inert-gas-shielded consumable-electrode process could be used for welding molybdenum. The major difficulties were associated with arc stability and metal-transfer through the arc. Minor problems involved (1) weld-bead contour, (2) weld cracking, and (3) porosity. It was thought that these minor problems might be solved once good welding conditions were established. Results of this investigation have indicated that this was true.

\section{$\underline{\text { Arc Stability and Metal Transfer }}$}

A stable arc is one which does not wander, remains constant in length, and is not extinguished frequently as a result of short circuits caused by large drops of molten metal. Arc stability and metal transfer are interrelated. If metal transfer is of a drop type rather than the preferred spray type, large drops can short-circuit the arc and cause sputtering. If the arc is not stable, metal transfer will be inconsistent. An unstable arc can also cause turbulence in the inert-gas shield and draw air into the shield. Good metal-transfer is of the spray type, occurring in the inner cone of the arc, with no spatter.

Initial welding studies were made using reverse polarity (electrode positive) on molybdenum sheet which had an oxidized surface. Conditions were established which appeared to be acceptable for welding molybdenum on oxidized sheets. However, when these welding conditions were used on molybdenum sheet from which the surface oxide had been removed, a very unstable arc resulted. Apparently the arc had been stabilized by the presence of molybdenum oxide on the sheet surface. The arc stability may have been aided by the molybdenum oxide film on the surface, molybdenum oxide vapor in the arc, or by the presence of oxygen in the inert-gas-shield. It has been shown in other investigations that it is difficult to obtain a stabilized arc on clean metal surfaces. (3) Oxygen additions are made to argon to aid arc stability for welding steels, and several investigations have shown that oxide films on the negative electrode aid in stabilizing the arc by increasing the emission of electrons. Since oxygen is highly detrimental to the ductility of molybdenum weldments, other methods were sought to stabilize the arc for welding on cleaned sheet.

Several variables were studied to determine their effects on arc stability and metal-transfer. These were: 
(1) Current density

(2) Direct-current polarity

(3) Shielding gas

(4) Shielding

(5) Emissive coatings.

The effects of these variables are summarized briefly in Table 2 .

\section{Current Density}

It is well known that current density plays a very important role in determining the type of metal transfer. At low current densities the metal transfer is of a largedrop type. In this type of metal transfer, the tip of the electrode melts until a drop forms which is large enough to be separated from the electrode by gravity. Above a certain current value, the metal transfer becomes the spray type. Minute drops of metal are separated from the electrode and propelled at high velocities as a fine spray by electromagnetic forces. It was found that when using reverse polarity in helium, a more stable arc resulted at higher currents. Exact current values for the transition from drop-type to spray-type metal transfer were not determined. Continued presence of spatter indicated that optimum conditions were not reached. Current densities of 300,000 to $400,000 \mathrm{amp}$ per in. ${ }^{2}$ were used with 0.040 -in.-diameter molybdenum electrodes and about $250,000 \mathrm{amp}$ per in. 2 was used with the 0.062 -in.-diameter electrodes. This is considerably more than the 100,000 to 150,000 amp per in. ${ }^{2}$ used with a $0.062-$ in.-diameter steel electrode in the normal welding range. In this study, current did not appear to have a great effect on arc stability and metal transfer for straight-polarity welding.

\section{Direct-Current Polarity}

A study was also made to determine the best $d-c$ polarity for welding molybdenum. Normally, for the welding of steel by the inert-gas-shielded consumable-electrode process, reverse polarity (electrode positive) produces the spray-type metal transfer mentioned above. On the other hand, straight-polarity (electrode negative) welding with an uncoated steel electrode produces large drops of molten metal at the tip of the electrode. Arc stability and metal transfer can be improved for straight-polarity welding by coating the electrode with a thin film of an emissive compound, as will be discussed later in this report.

Initial welding studies using the inert-gas-shielded consumable-electrode process were made with reverse polarity in helium. The arc was stable when the molybdenum sheet had an oxidized surface, but a stable arc could not be maintained on a clean surface. On a clean molybdenum surface the arc wandered considerably and was very unstable. Changing the polarity did not improve arc stability. With straight polarity in helium the arc length was constantly changing, while with straight polarity in argon the cathode spot could be seen moving up and down the electrode wire. The arc was not stable using either polarity without coating the cathode with a compound to increase 
TABLE 2. EFFECTS OF VARIABLES ON ARC STABILITY AND METAL TRANSFER 0.040-In.-Diameter Electrode, Helium Shielding Unless Noted Otherwise

\begin{tabular}{|c|c|c|}
\hline Variable(a) & Variation & Effect of Variation \\
\hline $\begin{array}{l}\text { Electrode current density } \\
\text { (direct current, reverse polarity) }\end{array}$ & $\begin{array}{l}160,000 \text { to } 365,000 \\
\text { amp per in. } 2\end{array}$ & $\begin{array}{l}\text { Arc more stable at higher } \\
\text { currents }\end{array}$ \\
\hline $\begin{array}{l}\text { Electrode current density } \\
\text { (direct current, straight polarity) }\end{array}$ & $\begin{array}{l}285,000 \text { to } 415,000 \\
\text { amp per in. } 2\end{array}$ & $\begin{array}{l}\text { Arc slightly more stable at } \\
\text { higher currents; arc "buried" } \\
\text { beneath plate surface at } \\
\text { highest currents studied }\end{array}$ \\
\hline Direct-current polarity & $\begin{array}{l}\text { Reverse polarity } \\
\text { (electrode posi- } \\
\text { tive) to straight } \\
\text { polarity (elec- } \\
\text { trode negative) }\end{array}$ & $\begin{array}{l}\text { More spatter with straight } \\
\text { polarity, neither condition } \\
\text { produced stable arc; straight- } \\
\text { polarity arc more easily } \\
\text { stabilized with emissive } \\
\text { coatings }\end{array}$ \\
\hline Shielding gas & Argon to helium & Better arc stability in helium \\
\hline Shielding devices & $\begin{array}{l}\text { Cup, leading- } \\
\text { trailing shield, } \\
\text { and dragging } \\
\text { shield }\end{array}$ & $\begin{array}{l}\text { Very little effect; less spatter } \\
\text { with improved shielding }\end{array}$ \\
\hline $\begin{array}{l}\text { Wire surface (direct current, } \\
\text { straight polarity) }\end{array}$ & $\begin{array}{l}\text { Clean to emissive } \\
\text { coating }(\mathrm{CsCl})\end{array}$ & $\begin{array}{l}\text { Erratic arc with clean sur- } \\
\text { face; emissive coating stab- } \\
\text { ilized the arc and allowed } \\
\text { lower burnoff rates to be } \\
\text { used at the same current }\end{array}$ \\
\hline $\begin{array}{l}\text { Sheet surface (direct current, } \\
\text { reverse polarity) }\end{array}$ & $\begin{array}{l}\text { Clean, slightly } \\
\text { oxidized surface, } \\
\text { emissive coat- } \\
\text { ing ( } \mathrm{CsCl} \text { ) }\end{array}$ & $\begin{array}{l}\text { Erratic arc with clean sur- } \\
\text { face; stable arc with either } \\
\text { emissive coating or oxidized } \\
\text { surface }\end{array}$ \\
\hline
\end{tabular}

(a) All other variables were held nearly constant when possible. 
electron emission. Even with the coating, the straight-polarity arc was not completely stabilized in argon. However, the weld beads produced with this polarity had better contour and penetration and were not as irregular in shape as reverse-polarity weld beads. When welding steel, much higher burnoff rates are realized when straight polarity is used. This effect was not observed with molybdenum.

\section{$\underline{\text { Shielding Gas }}$}

Previous welding studies using the tungsten-arc process indicated that helium was more suited for welding molybdenum than argon. (2) Welds made in helium had a better contour and deeper penetration than welds made in argon. Using argon and straight polarity, cathode instability was manifested by wandering of the cathode flame above the tip of the electrode. This phenomenon is not unusual when welding in pure argon, (4) Using helium and straight polarity, the cathode spot was stable on the end of the electrode, but the arc length was constantly changing. Emissive compounds on the electrode stabilized the arc length in helium but did not completely eliminate cathode instability in argon. These observations indicate that helium gives better arc stability than argon. Argon-helium or argon-hydrogen mixtures might give better arc stability than pure argon. Argon-hydrogen mixtures have been used for tungsten-arc welding to approach the heat developed using helium. (5)

\section{$\underline{\text { Shielding }}$}

Three shielding devices were used for this study: (1) a standard shielding cup, (2) a leading-trailing shield, and (3) a dragging shield. The shielding cup was found to be inadequate for shielding molybdenum because it did not prevent severe oxidation of the unwelded sheet ahead of the arc. Considerable spatter emanated from the weld area, causing some interruption of the inert-gas shield.

The leading-trailing shield provided better protection than the shielding cup. However, the shield could not be brought close enough to the weld to insure good protection. Spatter was lessened to some degree by the use of the leading-trailing shield, but was still enough to cause some shield interruption.

The dragging shield appeared to improve the inert-gas-shielding further. Some spatter was still evident, but it was confined within the shield and did not cause shield interruption.

In this study, no attempt was made to determine the effect of shielding on arc stability or metal transfer. The lowering of the amount of spatter achieved by improving the shielding indicates some degree of improvement in arc stability and metal transfer. No study was made of the effect of shielding or inert-gas flow rates on weldment ductility.

\section{Emissive Coatings}

The results of molybdenum welding tests using the inert-gas-shielding consumable-electrode process with straight polarity and a clean molybdenum electrode indicated that a method was required to improve the arc stability and metal-transfer characteristics using unoxidized materials. As a result of the better understanding of 
arc phenomena acquired in recent years, many advances have been made in the inertgas-shielded consumable-electrode welding process. One of the most significant of these advances is the use of coatings to increase the emission of electrons and thus aid arc-stability and improve the metal-transfer characteristics of straight-polarity welding arcs. Improvement in arc stability for straight-polarity welding of molybdenum was very important, since this polarity provided better appearing welds with deeper penetration and less cracking than did reverse polarity.

For many years, it has been known that the thermionic emission in electron tubes could be improved by surface coatings which lowered the thermionic work function of the cathode. The work function is a quantity related to the energy required to make an electron leave a surface; the smaller the work function, the lower the temperature at which a given electron emission can be attained. In the straight-polarity welding arc, it is impossible for a clean wire to support the arc by thermionic emission of electrons, since its area of emission is restricted and its work function is high. By coating the surface with a compound which lowers its thermionic work function, the mode of metal transfer with straight polarity is improved, metal drop size and spatter are reduced, and material movement becomes more axial. The arc then becomes stable, and has the same geometry as a reverse-polarity arc. Activated electrodes are now coming into use for straight-polarity welding of the more common metals. $(6,7)$

To lower the thermionic work function, a metal or metallic compound with an ionization potential less than that of the electrode material must be used for the coating. Metals or compounds of metals falling in the alkali, alkaline-earth, or rare-earth families are the best coating materials. (7) Oxides of metals generally have better emission characteristics than the pure metals. Only minute amounts of these compounds are required to activate the electrode. When argon-oxygen mixtures are used for welding steel, arc stability and metal transfer are improved. Iron oxide is formed on the electrode and increases the flow of electrons. Molybdenum oxide on the molybdenum cathode (negative electrode) may aid arc stability in much the same manner. This would account for the decreased arc stability when the oxide was removed by etching.

In the limited work done during this investigation, only cesium chloride coatings were used. Some of the initial work was done with the emissive compounds using reverse polarity. In this case, the sheet was coated with the compound. Arc stability was increased. The effect of the emissive compounds was more striking when the coated electrode was used for straight-polarity welding.

When the coated electrode was used for straight-polarity welding of molybdenum, the burnoff rate at a given current could be lowered below that required for an uncoated electrode. This means that, at a given burnoff rate, a coated electrode will produce higher currents and deeper penetration than an uncoated electrode. This is illustrated in Table 3.

In helium the arc length was constantly changing when an uncoated electrode was used. Coating the electrode with cesium chloride stabilized the arc length. In argon, the arc was not completely stabilized by coating the electrode. The cathode spot still wandered up and down the electrode. Considerable spatter was still very evident with straight polarity in helium or argon. Further work should be carried out using coated electrodes to improve arc stability and metal transfer and to study the effect of other variables on arc stability and metal transfer when coated electrodes are used. 
TABLE 3. EFFECT OF EMISSIVE COATINGS ON BURNOFF RATE AND CURRENT FOR STRAIGHT-POLARITY HELIUMSHIELDED WELDING OF MOLYBDENUM

\begin{tabular}{lcc}
\hline Coating & $\begin{array}{c}\text { Current, } \\
\text { amp }\end{array}$ & $\begin{array}{c}\text { Burnoff Rate, } \\
\text { ipm }\end{array}$ \\
\hline None & 400 & 400 \\
$\mathrm{CsCl}$ & 460 & 400 \\
$\mathrm{CsCl}$ & 400 & 325 \\
\hline \hline
\end{tabular}

\section{Spatter}

Spatter is simply the expulsion of drops of molten metal from the arc or weld area. Though spatter was much more noticeable when straight polarity was employed, it occurred with reverse polarity also. With straight polarity, metal is generally transferred through the arc as large drops. The erratic motion of these drops causes the arc plasm to shift, resulting in an acceleration of drops away from the weld in the form of spatter. Spatter may also be caused by mechanical agitation and explosion of large drops which touch the plate before being separated from the wire, causing short circuits. (6) In reverse-polarity welding of molybdenum spatter could have been caused by poor metal transfer.

No attempt was made to determine the cause of the spatter encountered. It was noted that the amount of spatter was lessened by improved shielding and by coating the wire with emissive compounds. Spatter is undesirable because it wastes filler metal and can cause interruption of the inert-gas shield.

\section{Weld-Bead Contour and Penetration}

Even though a stable arc was maintained with good metal transfer, the shape and contour of the weld bead had to be consistently acceptable. Penetration is very important in molybdenum welding, especially for the first pass of multipass joints, where complete penetration at the base of the joint is required. An ideal weld would have a low and nearly flat contour on the top surface. With pure metals or alloys having narrow freezing ranges, it is not possible to obtain such a contour because of the rapid freezing. In this study, weld-bead contour was usually regulated by changing the weld speed at conditions which produced a stable arc.

Weld beads made using reverse polarity were narrow and had a very high contour. Penetration was not very deep with reverse polarity. In one single-vee butt joint, the arc was slightly off center. This resulted in incomplete penetration at the joint base, and imperfect fusion between the weld bead and one side of the joint.

Straight polarity produced a weld bead with a wider and lower contour, very similar to straight-polarity beads in steel. In addition, much more heat was put into the plate when straight polarity was used, resulting in a marked increase in penetration. A single-vee butt joint was made with the arc to one side of the joint line, using straight 
polarity. Penetration was not complete, but unlike the similar weld made with reverse polarity, the weld bead was fused on both sides of the joint.

The weld beads described above were made in helium. Weld beads made in argon had less penetration and generally had a higher bead contour. As was suggested in a previous section, perhaps a mixture of argon and hydrogen could be used to duplicate the results found for helium.

The best weld-bead contour was produced by welding with straight polarity in helium using an emissive coating on the electrode at a relatively low burnoff rate ( 325 ipm with 0,040-in.-diameter wire). A high weld bead is due to the rapid freezing of the molybdenum, which does not allow time for the molybdenum to flow. The best weldbead contour was made at conditions which supplied the most heat into the weld, perhaps allowing a slightly longer time for molten filler metal to flow.

\section{Cracking}

Many of the butt joints made during the early portion of this investigation were badly cracked. These cracks were usually transverse to the weld and ran through some defect in the weld which caused a stress concentration or a reduced cross section. Basically, the difficulty stemmed from longitudinal stresses in the weld due to shrinkage. Cracking was a particularly serious problem when the butt joints were made using reverse polarity.

When polarity was changed to straight polarity, cracking was less evident. Since more heat was put into the molybdenum plate being welded when straight polarity was employed, the additional heat may have alleviated shrinkage stresses by acting as a preheat-postheat cycle, thus reducing the tendency for cracking. Further reduction in cracking might be realized by an additional preheat-postheat cycle.

In multipass single-vee butt joints, the first weld pass could be made without any cracks. Additional weld passes caused transverse cracks to develop in the first pass. These cracks then ran into the subsequent passes as the shrinkage stress was built up.

Longitudinal weld cracks appeared in a few multipass single-vee butt joints. Shrinkage of the weld metal in a direction transverse to the weld direction caused distortion, placing the root of the first weld pass in tension. If penetration by the first pass was not complete, a notch was present at the joint line. Then, when subsequent passes were made, longitudinal cracks could easily initiate at the notch and propagate in the first weld pass. Cracking due to shrinkage stresses might be eliminated by using a minimum amount of filler metal, or by making welds in a single pass.

It was mentioned previously that fractures occurred through some inconsistency in the weld bead where a reduced cross-sectional area or a stress concentration existed. Cracking tendencies of molybdenum weldments would be lessened to a large degree if weld beads could be made with a consistent cross section. Complete penetration of the first weld pass would eliminate longitudinal cracking due to the presence of a notch at the joint line. 
Porosity

Porosity was not a major problem with the inert-gas-shielded consumableelectrode welding of arc-cast molybdenum. The majority of welds were very sound, as shown in Figures 4 to 6 which appear later. Porosity was noted in some bead-on-plate welds when the arc was unstable, metal-transfer was poor, or shielding was inadequate. When welding conditions were good, very little porosity was noted, except at the starting end of the weld before the arc became stabilized.

\section{Butt Joints}

Welding conditions were evaluated during the investigation by making bead-onplate welds. From the conditions established for such welds, three sets of conditions were chosen as the best, and these were then used to make a series of butt joints in $1 / 4-, 3 / 8-$, and 1/2-in. -thick molybdenum plate. The specific conditions are given in Table 4. All joints discussed in this section were made using straight polarity. These conditions were used with slight modifications where they were deemed necessary.

TABLE 4. WELDING CONDITIONS CHOSEN FOR WELDING BUTT JOINTS

\begin{tabular}{ccccccc}
\hline $\begin{array}{c}\text { Arc } \\
\text { Voltage } \\
\text { Setting, v }\end{array}$ & $\begin{array}{c}\text { Burnoff } \\
\text { Rate, } \\
\text { ipm }\end{array}$ & $\begin{array}{c}\text { Approximate } \\
\text { Current, } \\
\text { amp }\end{array}$ & $\begin{array}{c}\text { Weld } \\
\text { Speed, } \\
\text { ipm }\end{array}$ & $\begin{array}{c}\text { Helium flow, cfh } \\
\text { 1-In. } \\
\text { Cup }\end{array}$ & $\begin{array}{c}\text { Dragging } \\
\text { Shield }\end{array}$ & $\begin{array}{c}\text { Electrode } \\
\text { Surface } \\
\text { Coating }\end{array}$ \\
\hline 32 & 400 & 400 & 20 & 150 & 150 & $\mathrm{CsC1}$ \\
32 & 325 & 400 & 20 & 150 & 150 & $\mathrm{CsCl}$ \\
32 & 605 & 520 & 25 & 150 & 150 & None \\
\hline \hline
\end{tabular}

Each of these conditions produced a different type of weld bead. The first set of conditions deposited a medium amount of filler metal with good penetration. A high, curved bead resulted. The second set of conditions produced a lower bead contour with good penetration, depositing less filler metal. The third set of conditions produced deep penetration and deposited a large amount of filler metal. Under the third set of conditions, the arc was "buried" beneath the plate surface. Emissive electrode coatings did not appear to be required when the arc was buried beneath the sheet surface.

Butt joints were made in 1/4-in. plate with the following joint designs: (1) square butt joints with 1/16-in. gap, and (2) single-vee joints with 30-, 60-, and 90-deg included angles. One single-vee joint with a 40-deg included angle was made in $3 / 8$-in. plate and a single-vee joint with a 40-deg included angle with a "U"-groove at the root was made in 1/2-in. plate. All joints had a small land at the root of the weld.

These initial tests using butt joints indicated that welding conditions established for bead-on-plate welds were not directly applicable to the welding of butt joints. Studies of various joint designs would probably be required to choose the proper joint for each thickness of sheet or plate, and for various welding conditions. The brief study of butt joints indicated that 0.040 -in. -diameter wire could be used for welding joints in 
$1 / 8-$ and 1/4-in. plate, and wire 1/16-in. or larger diameter would be required for $3 / 8-$ and $1 / 2-$ in. thick plate.

Comparison of Weldments

Two welds were made in 1/8-in. -thick molybdenum to compare the inert-gasshielded tungsten-arc and the consumable-electrode welding process. The conditions used to make these welds are given in Table 5. It was thought that a fine weld grain size would result from the consumable-electrode welding of molybdenum, thus increasing the ductility of the weldments as well as the tolerance for impurities.

The weld macrostructures can be seen in Figures 3 and 4 for bead-on-plate type welds made in 1/8-in. -thick sheet. These photographs indicate that the weld grain size is about the same for both welds. The grains in the consumable-electrode weld appear to be somewhat more columnar than those in the tungsten-arc weld. Penetration was excessive for the consumable-electrode weld. Possibly if less filler metal had been added by using less current, a finer weld grain size would have resulted. The heataffected zone was much broader for the consumable-electrode weld. This could be due to the excessive penetration or to the fact that the weld was not cooled by copper plates as was the case with the tungsten-arc weld.

The microstructures were very similar for the two welds. Figure 5 shows the microstructure for the consumable-electrode weld. The precipitate appearing in the grains and along the grain boundaries has been identified as molybdenum carbide.

The welds were ground flush, stress relieved 1 hour at $1800 \mathrm{~F}$ in helium, and sectioned for bend testing. The sheet was also stress relieved and bend tested. The bendtest data are given in Table 6. These data indicate no difference in ductility between the two welds. Sheet and weldment ductility were poor compared with the ductility of sheet used in previous welding studies (Sheet C3 in Table 6). Sheet C29 was tested with the bend line perpendicular to the rolling direction (normally the most ductile direction), while Sheet C3 was tested with the bend line parallel to the rolling direction. In spite of this, the tungsten-arc weld was considerably more ductile in Sheet C 3 than in Sheet C29, undoubtedly owing to the better structural quality of the molybdenum in Sheet C3. Definite conclusions concerning the ductility or weld-grain structure of consumableelectrode welds in molybdenum cannot be established using these initial tests.

A two-pass consumable-electrode weldment was sectioned for macroexamination (Figure 6). This weld was made in 1/4-in. -thick molybdenum plate using a single-vee joint with a $60 \mathrm{deg}$ included angle. The weld-metal grains appear to be slightly smaller in this weld than in the weld in 1/8-in. -thick sheet (see Figure 4). Grains at the center line of the weld are oriented perpendicular to the plane of the plate surface. This orientation could cause a lowering of tensile strength in a direction transverse to the welding direction.

From this limited comparison of weldments it appears that the consumableelectrode welding process would be more adaptable to the welding of thick plates of molybdenum. The tungsten-arc process appears better suited to the welding of sheet up to $1 / 8$ in. thick. 
TABLE 5. WELDING CONDITIONS FOR COMPARISON OF WELDMENTS

\begin{tabular}{|c|c|c|c|c|c|c|c|c|c|c|c|c|}
\hline \multirow[b]{2}{*}{ Weld } & \multirow[b]{2}{*}{ Process } & \multirow[b]{2}{*}{$\begin{array}{l}\text { Weld } \\
\text { Pass }\end{array}$} & \multirow[b]{2}{*}{$\begin{array}{l}\text { Current, } \\
\text { amp }\end{array}$} & \multirow[b]{2}{*}{$\begin{array}{c}\text { Arc } \\
\text { Voltage }\end{array}$} & \multicolumn{3}{|c|}{ Helium Flow, cfh } & \multirow{2}{*}{$\begin{array}{c}\text { Cup } \\
\text { Diameter, } \\
\text { in. }\end{array}$} & \multirow{2}{*}{$\begin{array}{l}\text { Weld } \\
\text { Speed, } \\
\text { ipm }\end{array}$} & \multirow{2}{*}{$\begin{array}{c}\text { Electrode } \\
\text { Burnoff Rate, } \\
\text { ipm }\end{array}$} & \multirow{2}{*}{$\begin{array}{c}\text { Electrode } \\
\text { Diameter, } \\
\text { in. }\end{array}$} & \multirow[b]{2}{*}{$\begin{array}{l}\text { Emissive } \\
\text { Coatings }\end{array}$} \\
\hline & & & & & Cup & $\begin{array}{l}\text { Dragging } \\
\text { Shield }\end{array}$ & Backup & & & & & \\
\hline $\mathrm{C} 29-6$ (a) & $\begin{array}{c}\text { Consumable } \\
\text { electrode }\end{array}$ & 1 & 470 & 32 & 150 & 150 & -- (b) & 1 & 20 & 605 & 0.040 & None \\
\hline $\mathrm{C} 29-8$ (c) & $\begin{array}{l}\text { Tungsten } \\
\text { arc }\end{array}$ & 1 & 425 & 18.5 & 40 & 150 & 30 & $5 / 8$ & 12 & - & $1 / 8$ & $\ldots$ (d) \\
\hline \multirow[t]{2}{*}{$\mathrm{C} 30-5(e)$} & $\begin{array}{c}\text { Consumable } \\
\text { electrode }\end{array}$ & 1 & 470 & 30 & 150 & 150 & - (b) $^{-}$ & 1 & 20 & 400 & 0.040 & $\mathrm{CsCl}$ \\
\hline & & 2 & 440 & 30 & 150 & 150 & $--(b)$ & 1 & $2 \theta$ & 325 & 0.040 & $\mathrm{CsCl}$ \\
\hline
\end{tabular}

(a) Penetration was excessive.

(b) No gas backup. A 1/16-in,-thick molybdenum backing strip was used to prevent copper pickup.

(c) Made in copper jig with gas backup. Better cooling of weld.

(d) Pointed thoriated tungsten electrode used.

(e) Single-vee joint, 60-deg included angle. 


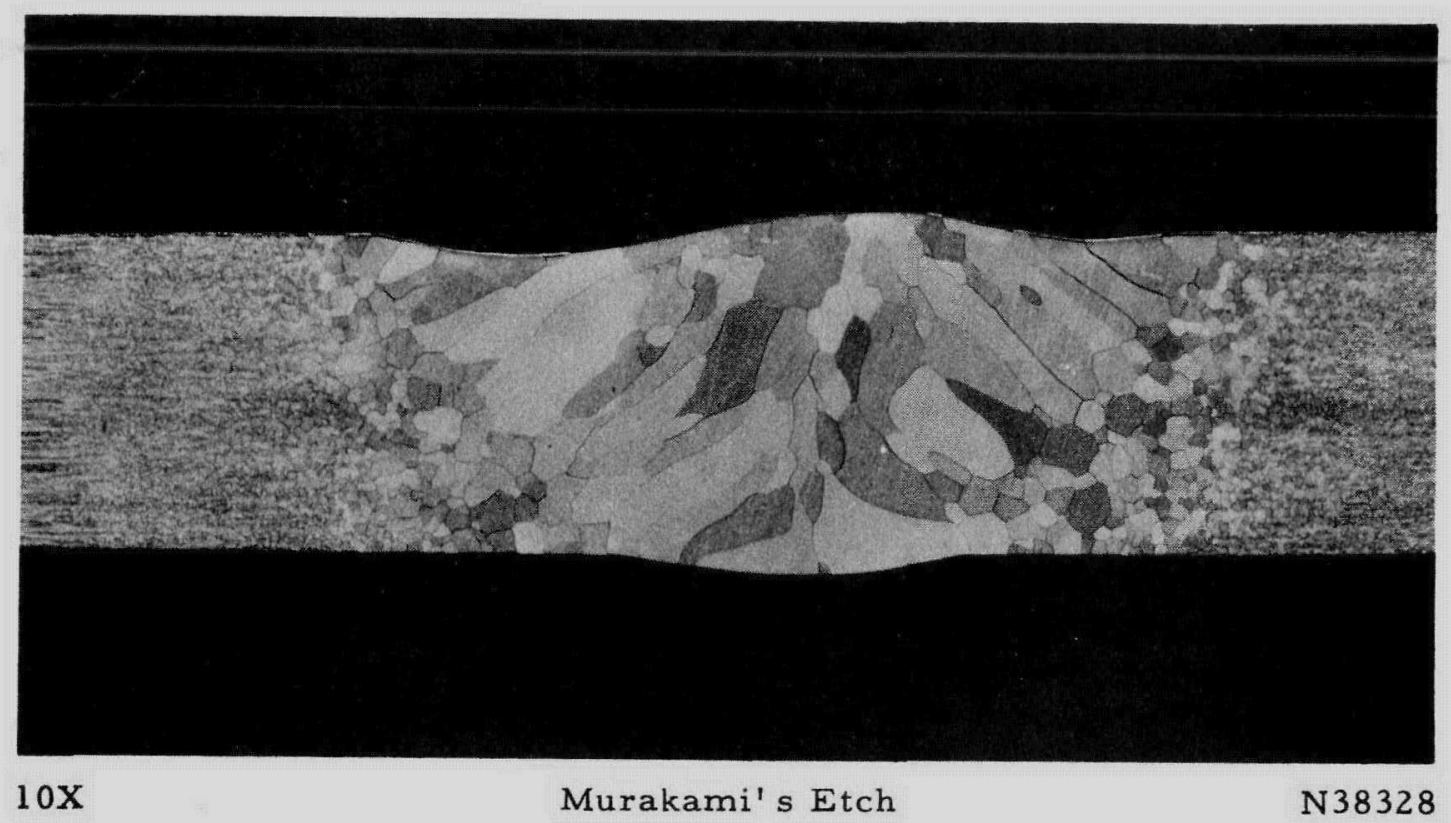

FIGURE 3. PHOTOMACROGRAPH OF TUNGSTEN-ARC WELD C29-8 $1 / 8$-in. sheet.

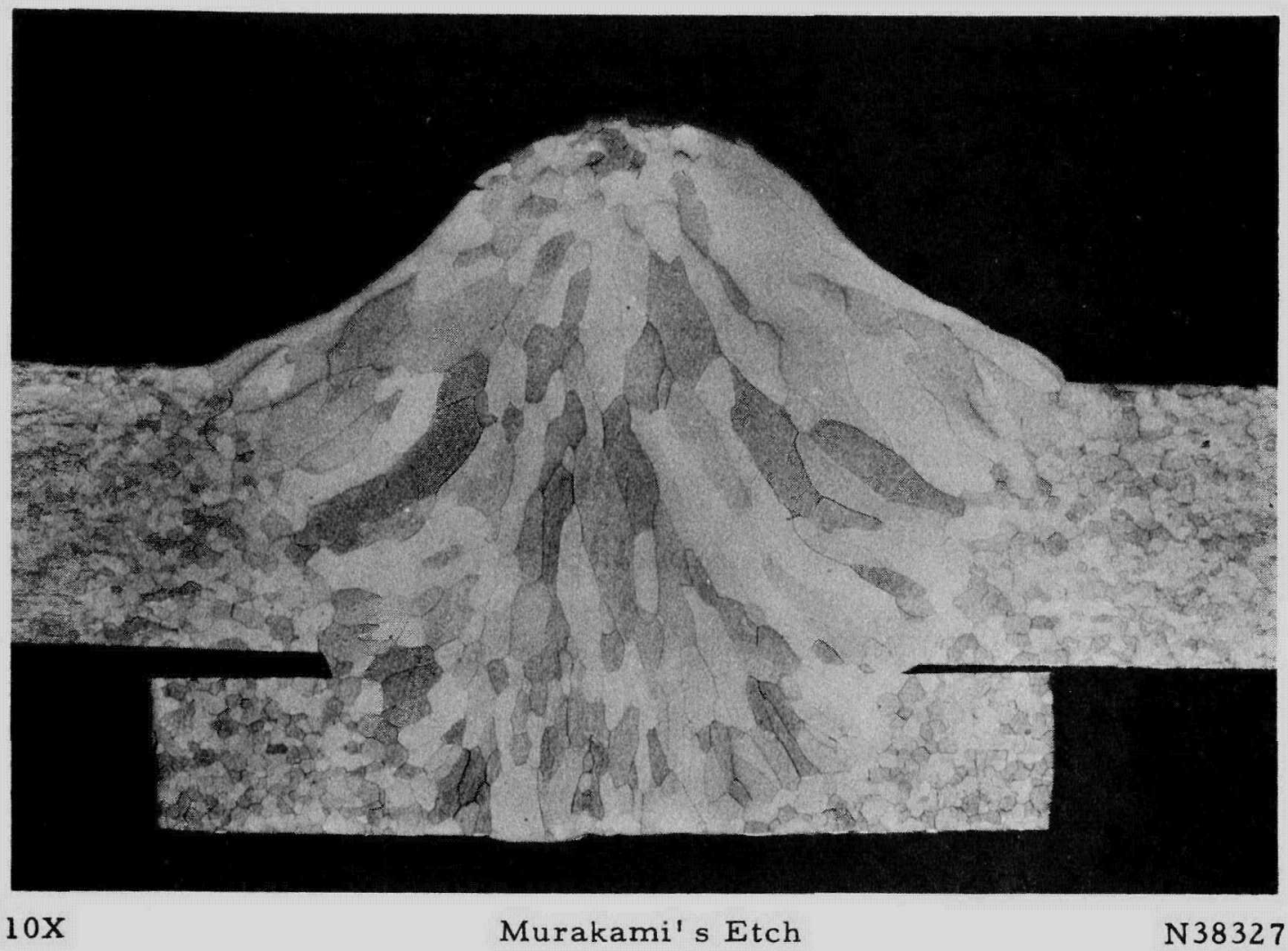

FIGURE 4. PHOTOMACROGRAPH OF INERT-GAS-SHIELDED CONSUMABLE-ELECTRODE WELD C29-6

1/8-in. sheet; 1/16-in. backing strip. 


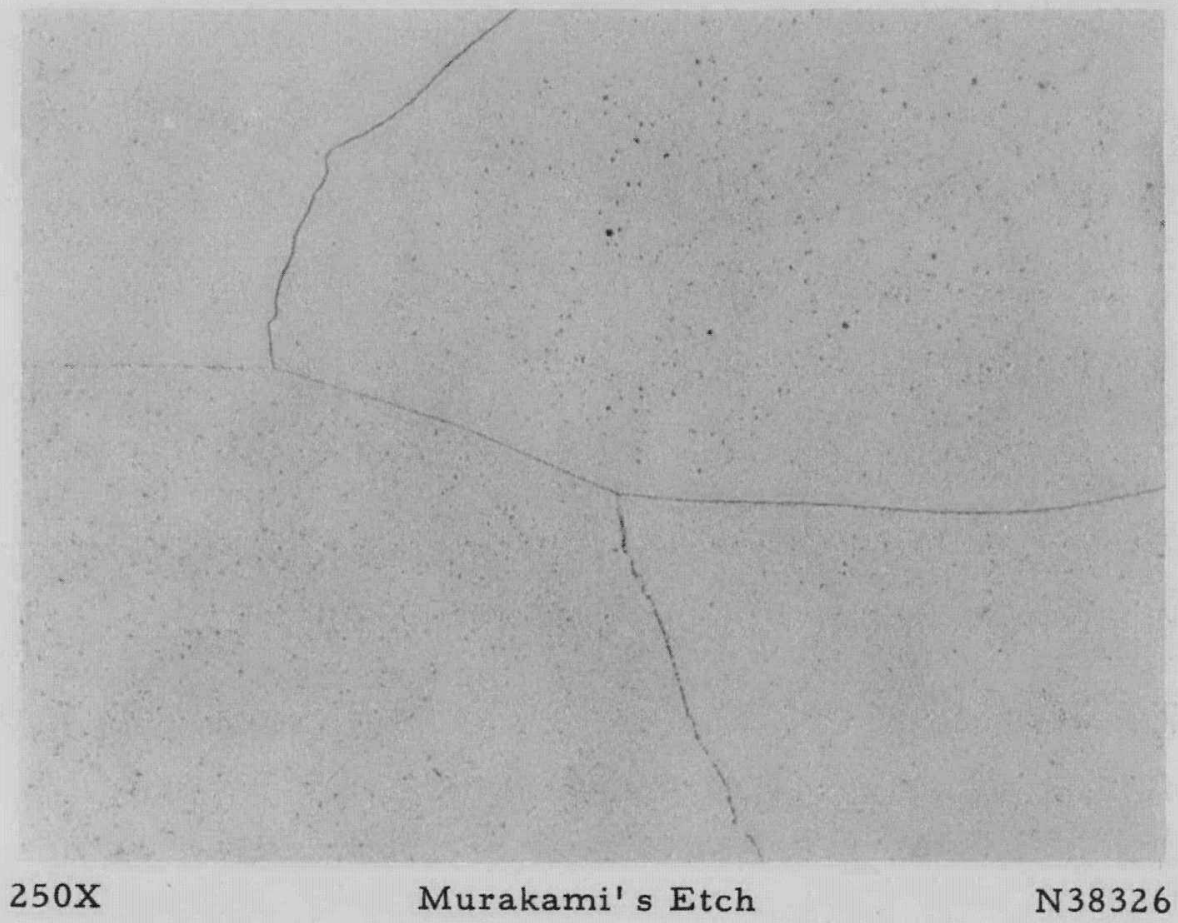

FIGURE 5. MICROSTRUCTURE OF WELD C29-6 SHOWING CARBIDES PRECIPITATED IN THE GRAINS AND ALONG THE GRAIN BOUNDARIES

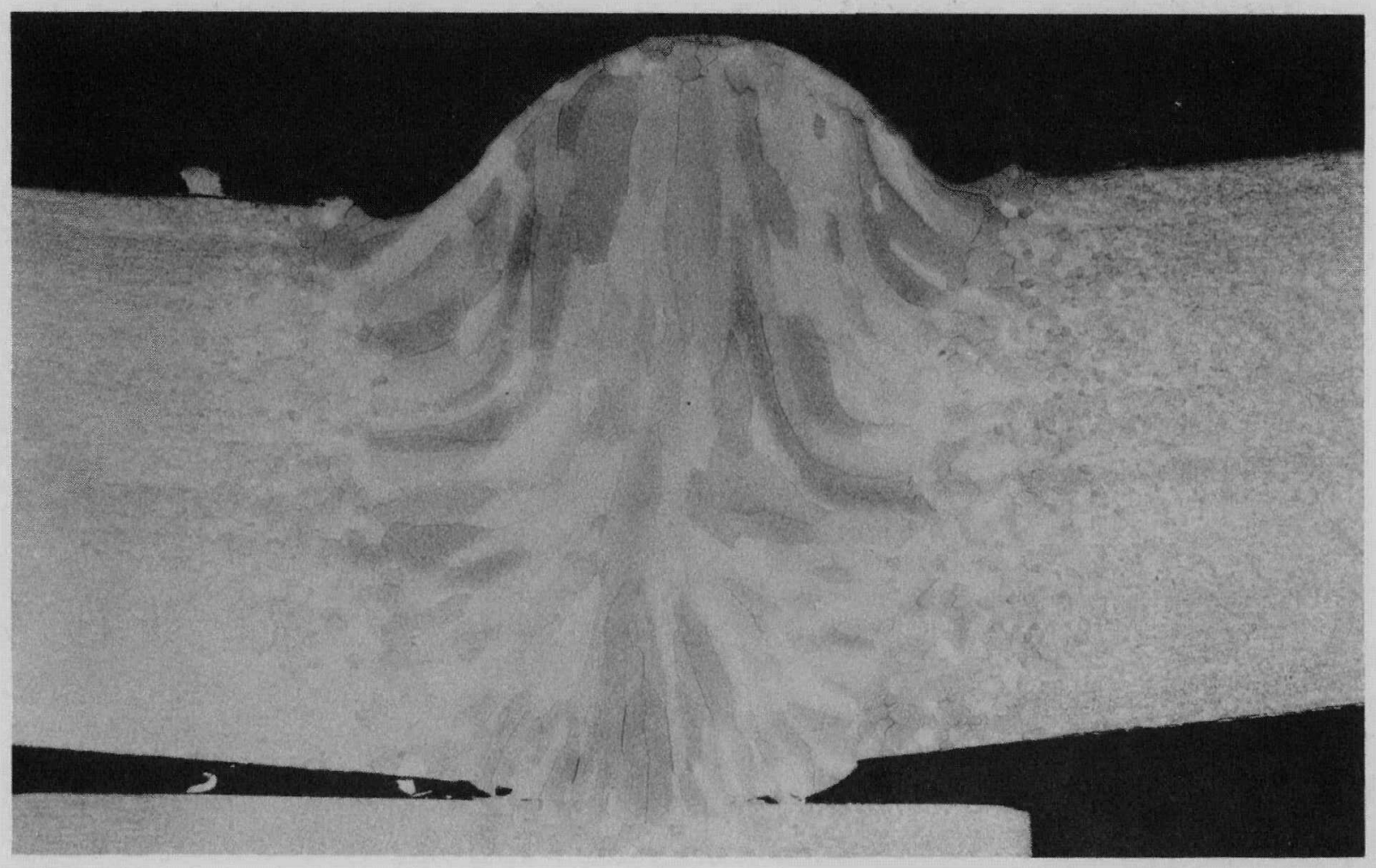

FIGURE 6. MICROSTRUCT URE OF A TWO-PASS CONSUMABLE-ELECTRODE WELD IN 1/4-IN. - THICK MOLYBDENUM PLATE (WELD C 30-5) 
TABLE 6. ROOM-TEMPERATURE BEND-TEST DATA FOR 1/8-IN. MOLYBDENUM SHEET AND WELDMENTS

\begin{tabular}{lccc}
\hline \hline Identification & $\begin{array}{c}\text { Carbon Content, } \\
\text { w/0 }\end{array}$ & $\begin{array}{c}\text { Welding } \\
\text { Process }\end{array}$ & $\begin{array}{c}\text { Permanent Bend Angle After } \\
\text { Fracture At 25 C, deg }\end{array}$ \\
\hline Sheet C29(a)(b) & 0.011 & - & $10,16,25,30,30,35$ \\
Sheet C3 $(\mathrm{c})(\mathrm{d})(\mathrm{e})$ & 0.041 & - & $50,85,90 \mathrm{NF}^{(\mathrm{f})}$ \\
Weld C29-6(a)(c) & 0.011 & $\begin{array}{c}\text { Consumable } \\
\text { electrode }(\mathrm{g})\end{array}$ & $2,2,2,2,4,4,4$ \\
Weld C29-8(a)(c) & 0.011 & $\begin{array}{c}\text { Tungsten } \\
\text { arc(g) }\end{array}$ & $2,2,4,4,4,4,4$ \\
Weld C3 $(\mathrm{b})(\mathrm{d})(\mathrm{e})$ & 0.041 & $\begin{array}{c}\text { Tungsten } \\
\text { arc(h) }\end{array}$ & $6,8,18$ \\
\hline \hline
\end{tabular}

(a) Stress relieved $1 \mathrm{hr}$ at $1800 \mathrm{~F}$ in helium.

(b) Bend tested longitudinal to the rolling direction.

(c) Stress relieved $1 \mathrm{hr}$ at $1800 \mathrm{~F}$ in hydrogen.

(d) Bend tested transverse to the rolling direction.

(e) From previous study (see BMI-1037(1)).

(f) $\mathrm{NF}=$ no fracture.

(g) Made with dragging shield.

(h) Made in high-purity dry-box atmosphere. 
FUTURE STUDIES

A complete evaluation of the inert-gas-shielded consumable-electrode welding process applied to molybdenum should consider more extended studies than reported here in the following areas:

(1) The effect of current density on the metal transfer of reverseand straight-polarity arc stability and metal transfer.

(2) The effect of gas mixtures of argon-helium and argon-hydrogen on arc stability and metal transfer.

(3) The effect of emissive coatings other than cesium chloride on arc stability and metal transfer.

(4) The effect of other variables on arc stability and metal transfer using emis sive-coated electrodes.

(5) The cause of spatter and methods of eliminating it.

(6) The effect of preheat-postheat cycles, other than the heat supplied by the welding arc, on cracking.

(7) The role of joint configuration in the quality of butt joints.

(8) The relative merits, as evaluated by weldment microstructures and bend-test ductility, of tungsten-arc and consumable-electrode welds in molybdenum, especially in thick plate.

In addition, several areas remain to be studied. These include studies of:

(1) Alternating current for welding molybdenum.

(2) An auxiliary magnetic field superimposed parallel to the arc to aid arc stability and improve metal transfer.

(3) The use of molybdenum with a slightly oxidized surface, with titanium additions to the molybdenum plate or wire to neutralize the deleterious effect of oxygen.

(4) The welding of $1 / 32$ - and 1/16-in. -thick sheet with 0.020 in. diameter electrodes to determine if the consumable-electrode welding process is adaptable for welding these thicknesses.

(5) The effectiveness of the shielding devices used in this study.

(6) The effects of changes in arc voltage. 


\section{REFERENCES}

(1) Weare, N. E., Monroe, R. E., and Rengstorff, G. W., "Fabrication and Welding of Arc-Cast Molybdenum", BMI-1037 (September 6, 1955).

(2) Weare, N. E., Monroe, R. E., and Martin, D. C., "Ductility of Tungsten-Arc Welds in Molybdenum", BMI-1 139 (October 10, 1956).

(3) Willeke, G. K., "The Electron Stream in the Inert-Gas-Shielded Arc", Electric Arc and Resistance Welding II, AIEE (December, 1950), pp 36-51.

(4) Ludwig, H. C., "Cathode Instability in Argon Atmospheres", Electric Arc and Resistance Welding IV, AIEE (July, 1954), pp 28-35.

(5) McElrath, T. E., Gorman, E. F., "Argon-Hydrogen Shielding-Gas Mixtures for Tungsten-Arc Welding", Welding Journal, 36 (1), 28-35 (1957).

(6) Lesnewich, A., "Electrode Activation for Inert-Gas-Shielded Metal-Arc Welding", Welding Journal, 34 (12), $1167-1178$ (1955).

(7) Cameron, J. M., and Basslock, A. J., "A Straight Polarity, Inert-Gas Process for Welding Mild Steel", Welding Journal, 35 (5), 445-449 (1956).

NEW:REM:DCM/mmk:vcz 